\title{
SANCTUARIES IN CANADA
}

P.S. TAYLOR, Canadian Wildlife Service, 115 Perimeter Road, Saskatoon, Saskatchewan S7N OX4 and C. JORGENSON, CWS, Box 280, Simpson, Saskatchewan. SOG 4MO

While encamped near the head of this lake in 1879 we had ample opportunity to examine this portion of the country. Multitudes of pelicans, geese, ducks, avocets, phalaropes, water hens and grebes besides innumerable snipe and plover were everywhere, in the marshes at the head of the lake, along its shores or on sand islands lying to the south of the camp. This was early in July and experience tells one that not one tenth was then seen of the bird life assembled in September and October. J.A. Macoun, 1879.

When the first yellow, peach, and pale green flares of dawn thrust upward to pierce the prairie night, the clamor of myriad birds fragments into the individual voices of a dozen species. Cranes, geese, ducks, swans, shorebirds - all join the welling chorus in growing agitation, stimulated by their hunger and the arrival of the day.

The full vermilion majesty of sunrise fills the eastern sky as the birds take to the air. Family units, then small flocks, then great skeins, wedges, and brigades of glorious birds begin to stream past in striking silhouette. Cranes are shy birds, and will veer off course at the first sight of you, so it is wise to keep still, and well hidden. The rolling resonant calls of the cranes and the ridiculous thin peeps of their young-of-the-year predominate, punctuated by the stirring honks of big gray Canada Geese and the high-pitched giggles of White-fronted Geese ... Throughout, Mallards quack sturdily, American Widgeon whistle, and the first pipits of the day lisp faintly overhead. J.A. Livingston, 1965.
In March 1887, Edgar Dewdney, then the Lieutenant-Governor of the Northwest Territories, wrote to Thomas White, Minister of the Interior urging him to reserve the islands of Last Mountain Lake as a wildfowl sanctuary, because rare pelicans nested in the region and during the breeding season the shorelines of the islands were "literally covered with eggs." 4 On 8 June 1887 the federal government reserved the first area for wildfowl in Canada at the north end of Last Mountain Lake (Long Lake) in what is now south central Saskatchewan; this area contained approximately 2,534 acres:

"whereas the Minister of the Interior has reported that the islands and shores of the northern end of Long Lake, in the North West Territories, are favourite breeding grounds for almost all the different varieties of wild fowl in that country, and that it is very desirable that steps be taken to retain these grounds for such purposes especially in view of the probable extension of the Long Lake Railway, and the consequent settlement of the land in that neighbourhood.

His Excellency in Council....hereby ordered the following lands which are vacant and unsold, be, and the same are herby reserved from sale and settlement, and set apart as breeding grounds for wild fowl..."

Sanctuaries in other provinces were not established until 1920, so Saskatchewan has the distinction of having the first bird sanctuary in Canada, indeed, in North America.

Murray recounts in detail the rather uneven history of the sanctuaries in Saskatchewan up to 1965, and it makes for interesting reading. ${ }^{8}$ In 1917 the Canadian 


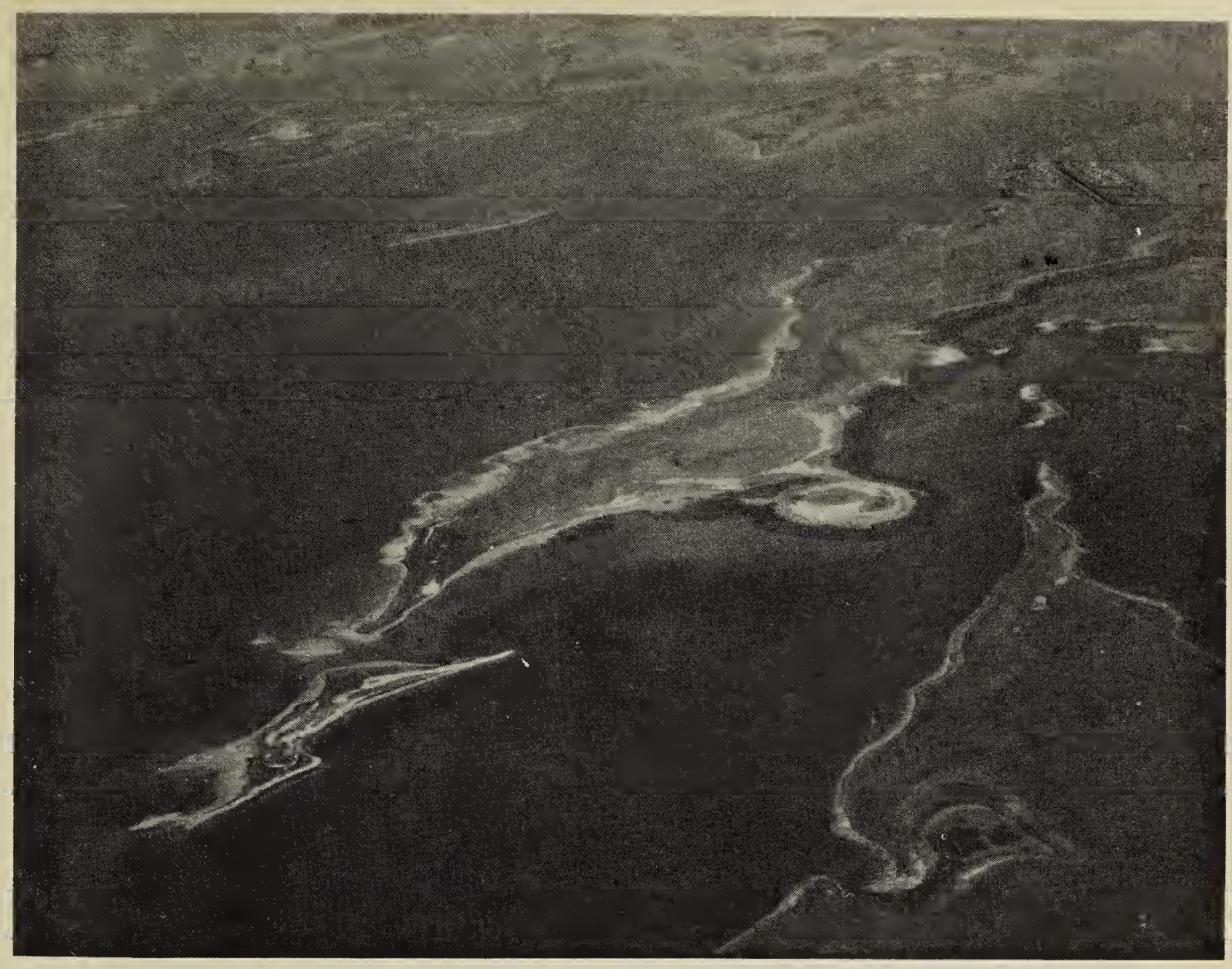

Perry's Point, foreground, and the islands at the north end of Last Mountain Lake were protected as Canada's first sanctuary for birds in 1887. White Pelicans nested successfully in the sanctuary in 1984 after many years of non-breeding.

P. Taylor

Parliament passed the Migratory Birds Convention Act and eight years later, twelve sanctuaries were formally established. These were: Last Mountain Lake, Lake Johnstone (Old Wives Lake), Quill Lakes, Lenore Lake, Basin and Middle Lakes, Chaplin Lake, Crane Lake, Bigstick Lake, Cabri Lake, Whitebear Lake, Redberry Lake, and Manito Lake. Soon after, the Experimental Farms at Indian Head and Sutherland were added as sanctuaries. These original sanctuaries included both the waters and islands of the lakes and, except for Cabri Lake, all vacant quarter sections of land immediately adjoining the lakes. Those lands had been reserved in 1915 to facilitate the establishment of the sanctuaries and prevent their sale and settlement.
Grazing leases in existance before the sanctuaries were established were modified. so that they were only valid if the restrictions on wildiife were observed.

In 1925 Public Shooting Grounds were established to complement the sanctuaries, "to encourage and foster a spirit of sportsmanship" and protect more wetland and upland habitat for wild fowl throughout the year. These were the following lakes: Good Spirit, Willow Bunch, Lake of the Rivers, Twelve Mile, Eagle, jackfish and Murray, Ponass, Muddy, Shallow, Goose and Cypress. Thus the twelve original sanctuaries and the twelve public shooting grounds reserved most of the large lakes in the southern part of Saskatchewan for wildlife at this early date. 


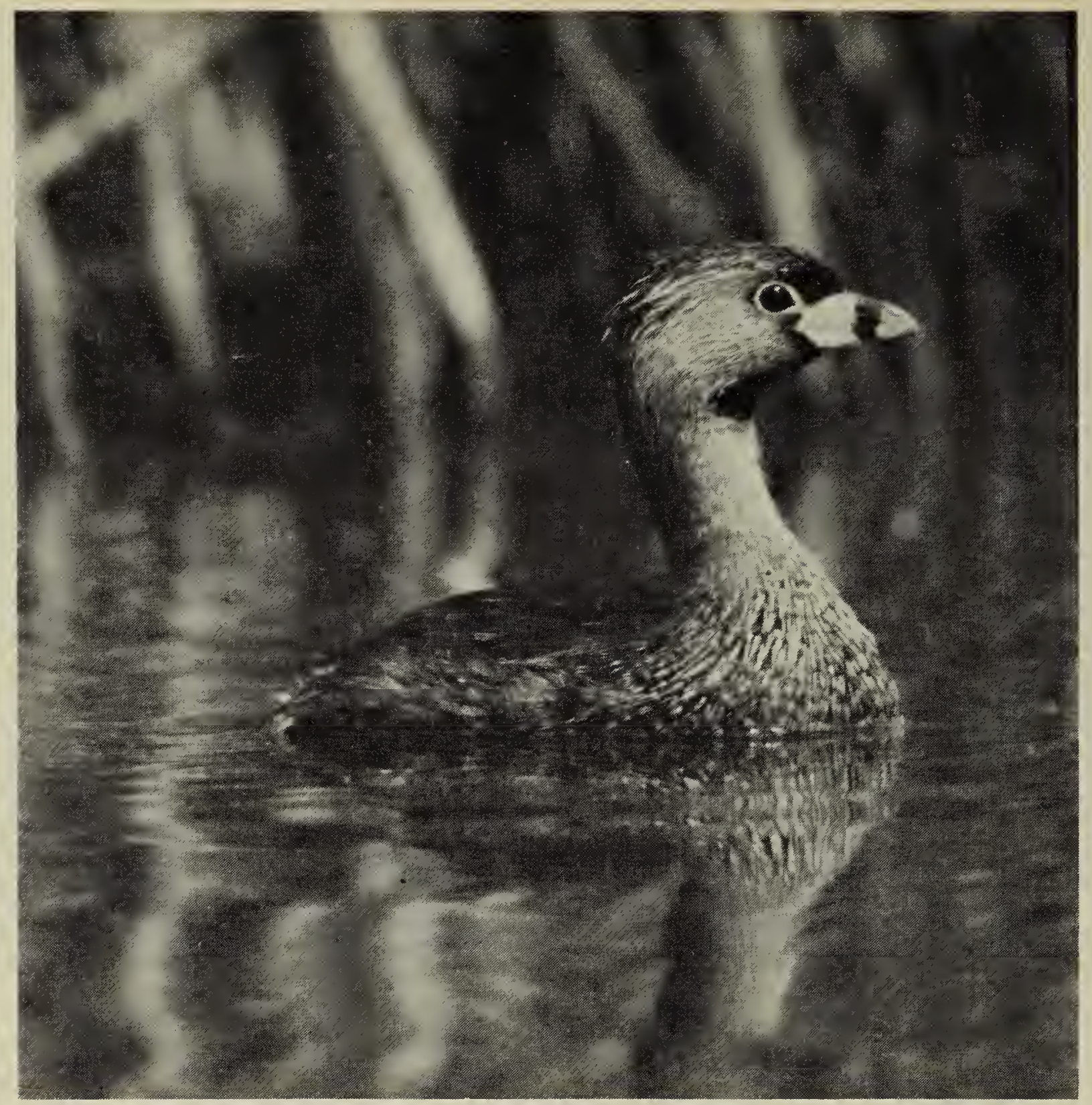

Pied-billed Grebe is one of over 90 species recorded as breeding at the north end of Last Mountain Lake

G. Beyersbergen

After this impressive start time wore away at the sanctuaries. Drought made some of the land unsuitable for sanctuary purposes and Chaplin, Crane, Bigstick, Cabri and Whitebear were delisted in 1948 and were replaced by Val Marie.and Duncairn Reservoirs and Murray, Scent Grass, and Upper Rousay Lakes. By 1956 Quill and Manito Lake sanctuaries were also delisted and were replaced by Neely and Opuntia Lakes, and Wascana.

Perhaps the most devastating blow to the sanctuaries was the loss of upland habitat surrounding all the lakes reducing the sanctuaries to water levels from day to day and to the islands. Only at Last Mountain Lake was the adjacent upland retained. Some 66,000 acres of land included in the sanc- tuaries in 1925 was reduced to less than 4000 acres by 1956 ! Agriculturalists, concerned over the need for more pasture land, over the unsupervised use of reserve areas in which the no-trespass rule was not enforced and over the infestation of such areas by weeds put pressure on the authorities to begin the process of removing the upland habitats from the sanctuaries. In 1951 the Public Shooting Grounds were abolished at the request of agriculture.

Despite the great set backs to the prairie sanctuaries, the sanctuary idea took hold across Canada. Today there are over 80 sanctuaries, from the Atlantic to the Pacific and north into the Arctic Islands, administered by the Canadian Wildlife Service. It is an impressive list totalling over 


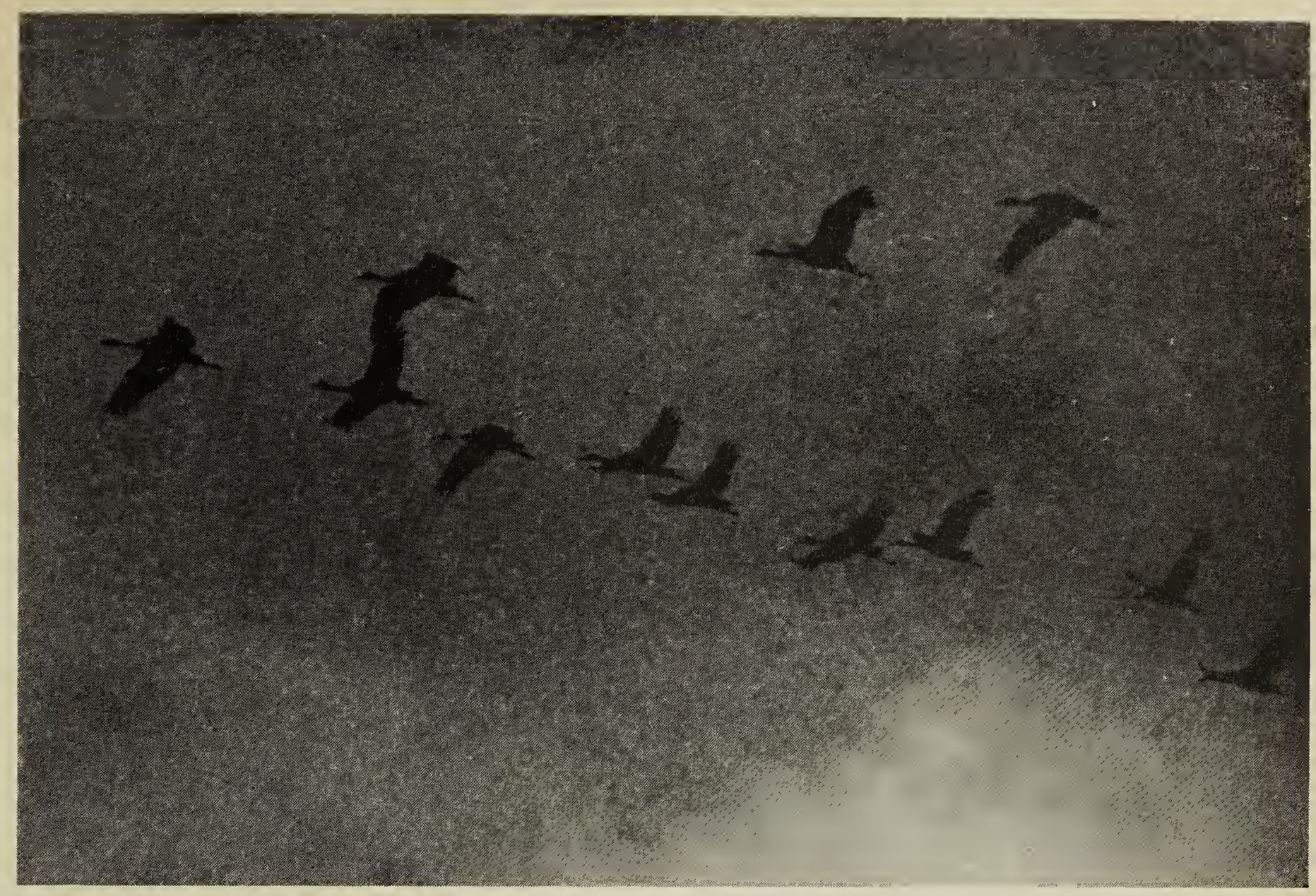

Sandhill Cranes stage in impressive numbers at the north end of Last Mountain Lake along with the endangered Whooping Crane.

S. Woynarski

10.2 million hectares (25.2 million acres). They range from small islets only a few hectares in area up to Queen Maud Gulf Bird Sanctuary totalling 6.3 million hectares. There are 39 sanctuaries in Ontario, Quebec and the Maritime Provinces, 26 in the Prairie Provinces and British Columbia, and 16 in the Northwest Territories.

The concept of federal wildlife lands came-of-age in 1973 with the passage of the Canada Wildlife Act. This legislation permits the Canadian Wildlife Service to preserve and maintain important or unique lands acquired for wildlife, especially migratory birds, and rare and endangered species, across Canada. Today more than $40 \mathrm{Na}$ tional Wildlife Areas have been established, including seven is Saskatchewan. Last Mountain Lake is the eighth aręa and is currently managed in cooperation with the province. Negotiations are underway to establish it formally as a National Wildlife Area.

National Wildlife Areas are a place for wildlife. They exist in every province except
Newfoundland and Prince Edward Island. Several are being considered for the Northwest Territories and the Yukon. One such area in the Northwest Territories would protect Polar Bear Pass, a unique high arctic oasis on Bathurst Island. Sizes vary, but each wildlife area has a special significance for some form of wildlife: Cap Tourmente National Wildlife Area in eastern Quebec contains the mud flats that attract the world's only flock of Greater Snow Geese in the spring and fall; Vaseux-Bighorn National Wildlife Area in British Columbia's Okanagan valley not only includes part of Canada's only desert, but a crucial wintering range for the endangered California Bighorn Sheep; the Mary's Point section of Shepody National Wildlife Area, at the eastern end of the Bay of Fundy in New Brunswick, protects the mud flats and gravel beaches where hundreds of thousands of shorebirds rest and feed on their southward migration; Long Point $\mathrm{Na}$ tional Wildlife Area in southern Ontario is the most extensive example of sand dunes and native vegetation in natural condition 
around the Great Lakes. Some plants and wildlife in its teeming marshes are more typical of the Carolinas than of Canada and Last Mountain Lake attracts thousands of migrating ducks, Sandhill Cranes and geese, as well as the endangered Whooping Cranes. Each area is a home for many creatures drawn by some special combination of topography, soil, vegetation and water.

National Wildlife Areas while established and managed to protect wildlife are also places for people. The management programs for an area consider how both wildlife and people can use the area without disrupting the habitat and disturbing the wildlife.

In most areas, hunting, hiking, photography, fishing, birdwatching, snowshoeing and canoeing are permitted. Trails and viewing stands help visitors understand their surroundings and the wildlife, and the relationships between them. But where the habitat is particularly fragile, even hiking is limited. Wildlife areas provide opportunities to see wildlife in a natural setting, to experience a spectacle such as massive flocks of Canvasback and Redhead ducks migrating through St. Clair and Long Point National Wildlife Areas in Ontario. They offer the chance to learn about and appreciate wildlife habitats and to re-establish our ties with nature.

The Migratory Bird Sanctuaries across Canada also protect a wide array of species during breeding, migration and wintering periods. They include the breeding grounds of Atlantic Puffins, Northern Gannets, Ivory Gulls, Snow and Ross' Geese, Tundra Swans, White Pelicans to name a few; migration staging areas in the prairies, and the coasts for arctic geese, Whooping Cranes, shorebirds plus a host of other birds; and the wintering quarters for shorebirds and waterfowl in British Columbia and the Maritimes.

Many of the sanctuaries offer excellent opportunities for viewing migratory birds and other wildlife, while still respecting the original purpose of protection for the birds. ${ }^{3}$

Celebrations to commemorate Canada's first Migratory Bird Sanctuary are planned by the Canadian Wildlife Service, the Province of Saskatchewan and public interest groups. Participation by the Saskatchewan Natural History Society and others will play a vital role in ensuring success of the centennial in 1987. It will be an opportunity for us as Canadians to appreciate the foresight shown by Sir John A. MacDonald, Thomas White, Edgar Dewdney and many others in protecting the first area for wildlife in Canada and to rededicate our efforts to protect Canada's wildlife heritage through the next 100 years.

' ANWEILER, G.G. 1970. The birds of the Last Mountain Lake Wildlife Area, Saskatchewan. Blue Jay 28:74-83.

${ }^{2}$ CANADIAN WILDLIFE SERVICE. 1980. Bird checklist, Last Mountain Lake Wildlife Management Unit. Canadian Wildlife Service Publ.

${ }^{3}$ FINALY, J.C. 1984. A bird-finding guide to Canada. Hurtig Publishers, Edmonton.

${ }^{4}$ FOSTER, J. 1978. Working for Wildlife; the Beginning of Preservation in Canada. University of Toronto Press, Toronto.

5 HATFIELD, J.P., 1965. Last Mountain Lake Bird Sanctuary and vicinity, Saskatchewan. Natural History Notes. Canadian Wildlife Service Publ.

${ }^{6}$ HEWITT, G. 1921. The conservation of the wildlife of Canada. Scribners, New York.

7 LIVINGSTON, J.A. 1965. The cranes at Last Mountain Lake, pp. 371-377 in The bird watcher's America. Ed. O.S. PETTIGILL, McGraw-Hill, New York.

8 MURRAY, L.H. 1966. Bird sanctuaries in Saskatchewan, 1887-1965. Blue Jay 24:110-120.

${ }^{9}$ PROUDFOOT, D. 1979. Fixed assets. Nature Canada 8(3):12-19.

10 THOMPSON, D. 1979. Secret wildlife areas. Outdoor Canada, May Issue: 29-32. 